\title{
NEW IDEAS FOR OLD LANDSCAPES: USING A SOCIAL-ECOLOGICAL APPROACH FOR CONSERVATION OF TRADITIONAL RURAL BIOTOPES - A CASE STUDY FROM FINLAND
}

\author{
Traci Birge, Marianne Fred ${ }^{1}$
}

Received 31 March 2011; Accepted 23 September 2011

\begin{abstract}
Traditional rural biotopes (TRBs) are high nature value farmlands (HNV). There are only 20.000 ha of identifiableTRB left in Finland. Ecosystem services were explored as a way of better understanding the value of TRBs to society. Postal questionnaires were sent out to all farmers in Raasepori Municipality in SW Finland to locate TRBs. Frequency of on-farm tourism, direct sales and services to the public were compared between farms with and without TRBs. Return rate for questionnaires $(n=326)$ was $40 \%$. Farms with TRBs had a higher rate of services and sales to the general public. A third of respondents with TRBs said their TRBs provide non-agricultural goods or services and $1 / 4$ said their TRBs are utilized by people from off-farm. Changes in policy toward more evidence-based approaches, adaptive management and consideration of ecosystem services could improve conservation of TRBs.
\end{abstract}

Key Words: traditional rural biotopes, cultural landscapes, social-ecological inventory, adaptive management, High Nature Value farmland, Finland, semi-natural meadows, agrienvironmental scheme (AES)

Sammanfattning: I Finland finns bara 20000 ha vårdbiotop kvar som kan kännas igen som sådana. Vi har granskat en adaptiv förvaltningsmodell med mål att upprätthålla och bevara vårdbiotop. För att få en mer omfattande bild av vad vårdbiotopernas betydelse har vi utrett vilka ekosystemtjänster vårdbiotoper består samhället med. För att lokalisera vårdbiotop skickade vi per post ut ett frågeformulär åt alla jordbrukare i den västnyländska kommunen Raseborg. Fyrtio procent av alla som fick frågeformuläret $(n=326)$ svarade. Vi jämförde i vilken mån jordbruk med eller utan vårdbiotop har turismverksamhet och/eller direktförsäljning, och det visade sej att fler jordbruk med vårdbiotop har dessa tilläggsverksamheter än jordbruk utan vårdbiotop. En tredjedel av de svarande med vårdbiotop meddelade att deras vårdbiotop också ger produkter som inte direkt är kopplade till jordbruk och en fjärdedel sade att även utomstående personer använder sej av deras vårdbiotop. Bevarandet av vårdbiotop skulle gynnas av att beakta de ekosystemtjänster de består samhället med, och genom att ta i bruk en adaptiv förvaltningsmodell.

\footnotetext{
1 ARONIA Coastal Zone Research Team, Åbo Akademi University and Novia University of Applied Sciences, Tammisaari, Finland; traci.birge@novia.fi, mafred@abo.fi
} 
Nyckelord: vårdbiotoper, kulturlandskap, social-ekologisk inventering, adaptiv förvaltning, jordbruksmark med höga naturvälden (HNV), Finland, jordbrukets miljöstöd, ekosystemtjänster

Tiivistelmä: Suomessa on jäljellä enää 20.000 ha tunnistettavissa olevia perinnebiotooppeja. Mukautuvaa hallinnointitapaa tarkasteltiin perinnebiotooppien ylläpidon ja suojelun näkökulmasta. Perinnebiotooppien merkitystä yhteisölle yritettiin kattavammin ymmärtää ottamalla huomioon niiden tuottamia ekosysteemipalveluja. Perinnebiotooppien paikallistamiseksi kaikille lounaissuomalaisen Raaseporin kunnan maanviljelijöille lähetettiin postikysely $(n=326)$. Maatiloilla tapahtuvan matkailutoiminnan, suoramyynnin ja palveluiden tarjonnan yleisyyttä vertailtiin tiloilla joilla on perinnebiotooppeja suhteessa niihin joilla ei ole. Kyselyn palautusaste oli $40 \%$. Yleisölle suunnattuja palveluita ja myyntiä oli enemmän tiloilla joilla on perinnebiotooppeja. Vastaajista kolmasosan mielestä heidän perinnebiotooppinsa antavat myös maatalouteen liittymättömiä tuotteita ja palveluita, ja neljäsosan mukaan heidän perinnebiotooppeja hyödyntävät tilan ulkopuoliset ihmiset. Perinnebiotooppien suojelua voisi parantaa niiden tuottamien ekosysteemipalveluiden huomioiminen ja siirtyminen entistä mukautuvampaan hallinnointitapaan.

Avainsanat: perinnebiotoopit, kulttuurimaisemat, sosiaali-ekologinen kartoitus, mukautuva hoito, Iuontoarvoiltaan arvokkaat maatalousmaat (HNV), Suomi, maatalouden erityisympäristötuet, ekosysteemipalveluita

\section{Introduction}

\section{Traditional rural biotopes}

Traditional rural biotopes (TRBs) are semi-natural farmland habitats formed through traditional agri-cultural activities, such as grazing and fodder collection. These multifunctional biotopes have historically been managed to provide specific ecosystem services (primarily fodder, but also wood, wild food items and agricultural crops). TRBs are usually extensively managed and rich in species diversity, including rare and endangered species (e.g. Pitkänen \& Tiainen 2001; Pykälä 2000). Changing demographics and changes in land use (either intensification or abandonment) are two driving forces threatening the continued existence of TRBs (Raunio et al. 2008).

TRBs are classified by the European Union's (EU) Environmental Commission as High Nature Value (HNV) farmlands (Beaufoy \& Cooper 2009). Indicators of HNV farmland are: presence of semi-natural characteristics of agricultural land, mosaic landscape structure and/or low intensity land use (Andersen et al. 2003). These qualities are often all present on TRBs simultaneously. Low-intensity livestock production on unimproved vegetation that is grazed, browsed, or cut for hay is widely recognized as "the farming of most value for biodiversity conservation across Europe" (Beaufoy \& Cooper 2009). TRBs are included in the EU's concept of multifunctional agricultural landscapes (EEA 2010).

TRBs in Finland are designated under the EU Habitats Directive as Special Areas of Conservation and, as such, are included in Finland's Areas of National Responsibility (Raunio et al. 2008). Conservation of Baltic coastal meadows and other endangered habitat types is transposed into Finnish law through the Finnish Nature Conservation Act (1096/1996), which lists, for example, low-growth seashore grasslands as protected biotopes.

There are approximately 20,000 ha of TRBs left in Finland, of which half are managed (Vainio et al. 2001). TRB area in Finland can only be roughly estimated for several reasons. Shifting TRB land use priorities from primarily agricultural to conservation oriented goals have resulted in changes in how TRBs are defined. Regular statistics on TRBs are not collected, and historical records have to be adapted to current definitions of TRBs (Raunio et al. 2008). Further, only a small proportion of the managed area still retains characteristics of traditionally-managed 
TRBs (Vainio et al. 2001). Identification of TRBs and their borders is complicated by abandonment and associated overgrowth (ibid). What is known is that Finland now has less than $1 \%$ of the meadows it had at the end of the $19^{\text {th }}$ century (Pitkänen \& Tiainen 2001). Over $90 \%$ of the TRBs still in existence in Finland are threatened and over $70 \%$ are critically endangered (Raunio et al. 2008). Both the quantity and quality of meadows and grazed woodlands are declining, although the rate of decline varies according to TRB type and drivers of change (Raunio et al. 2008). Reasons for TRB decline vary across types, but the most important threat to TRBs generally is overgrowth as a result of end of grazing and haying of TRBs (ibid). For some seashore meadows, the primary threats are eutrophication and construction along shorelines, dredging and other changes to the coastal zone (Raunio et al. 2008). Over time, decreases in TRB quality result in reduction or disappearance of defining characteristics of TRB types until they can no longer be identified as TRBs according to indicator species, physical attributes or land use.

Conservation of TRBs at the national and EU levels is driven primarily by concern for habitat loss and decreases in associated biodiversity, but also by historical and cultural values. Conservation has been legislated and managed through multiple programmes and special designations that either provide incentives to encourage management of TRBs or regulations to limit activities that harm the traditional nature of the biotopes. The primary European legislative mechanisms for TRB conservation are voluntary agri-environmental schemes (AES) for farmers and the non-voluntary Natura 2000 environmental programme. AES are so-called " $3^{\text {rd }}$ tier" voluntary, incentive based subsidies based on 5 or 10 year contracts. EU rural development regulation obligates member states to have AES (EEA 2004). AES amongst member states are highly variable. In Finland, there is AES specifically for management of TRBs. Additionally, AES for landscape and biological diversity is often applied to TRBs in Finland.

\section{Using evidence-based science and holistic approaches for TRB conservation}

Both effective strategies and sufficient resources are needed for conservation. Multiple tools and conceptual frameworks for addressing complex conservation issues have been developed in recent years. These tools lean towards integrated approaches to conservation, and emphasise stakeholder participation and learning-feedback. Evidence-based conservation, adaptive management (AM), ecosystems services (ES) and social-ecological system framework (SES) are complementary approaches that may be useful for improving the effectiveness of TRB conservation and management.

Knowledge grounded in evidence of the impacts of management techniques is necessary for effective conservation strategy. Development of conservation management for European cultural landscapes has been based on experiential knowledge of individual managers and mainly has tried to mimic historical land management practices (Pullin \& Knight 2003). This approach is used in part because of a lack of scientific evidence about the most effective management to meet conservation goals (Pullin \& Knight 2003). Shortcomings of relying nearly exclusively on anecdotal and dated methods in a changing environment are that it can lead to dogma that is either ineffective or wrong (Pullin \& Knight 2003). Evidence-based conservation management, which uses systematic reviews, and tests answerable questions using the scientific method, provides a scientific knowledge base that helps decision-makers evaluate the effectiveness of management strategies (Sutherland et al. 2004; Pullin \& Knight 2003).

Similar to evidence-based conservation, adaptive management (AM), seeks to improve conservation by building a knowledge base of what management works. AM is a "learning by doing" iterative process that increases system knowledge through a structured feedback mechanism (Allen et al. 2010). AM is "designed primarily to help managers better understand complex ecological systems by monitoring the results of a suite of management initiatives" (Gregory et al. 2006). The multiple conservation and agricultural goals of TRB management and the participation of a range of stakeholders suggest that TRB management could benefit from AM. AM and evidence-based conservation are complementary tools in conservation.

Another tool for understanding multiple components of a system is ecosystem services (ES). Evaluation of ES helps conceptualise how society benefits from ecosystems. The Millennium 
Ecosystem Assessment (MA) of the United Nations Environment Programme (UNEP) and partner organizations define ES as:

"...the benefits people obtain from ecosystems. These include provisioning, regulating and cultural services that directly affect people and supporting services needed to maintain the other services" (Millennium Assessment 2003).

ES of TRBs range from cultural and provisioning services to regulating and supporting services. ES provided by TRBs are largely under-researched. In Finland, for example, both academic research and government inventories of TRBs tend to focus predominately on biodiversity, while a few programmes have also considered the provisioning services of fodder production (i.e. Agri-food Finland's LUMO laidun project).

ES links human wellbeing inseparably to the ecosystem underpinning it. How humans and the environment interact is the basis of the social-ecological system framework (SES), where humans are considered a part of the ecosystem rather than separate from nature (HainesYoung \& Potschin 2010; Berkes, Colding \& Folke 2008). SES makes explicit the links between the social and ecological components of a system, including drivers of change and responses to feedback (Haines-Young \& Potschin 2010). SES relies on evidence-based science to understand the multiple system components. The SES concept is an explicit component of the ecosystem services concept (MA 2003) and is compatible with the AM and evidence-based conservation approaches.

\section{Research aims}

Social-ecological inventories have been proposed as an early-planning tool in conservation projects as a way to ascertain what knowledge is held by local ecosystem stewards and to identify their motivations and management activities (Schultz et al. 2007). When focused on information held by stakeholder groups outside of official channels, the social ecological inventory can provide a tool for identifying informal or unregistered management and knowledge that may otherwise not be considered in management planning (Schultz et al. 2007). This study is a first step in conducting a social-ecological inventory of TRBs in Raasepori municipality.

The broad aims of the postal questionnaire were to identify farmers that manage or own TRBs and determine whether TRBs provide non-agricultural direct use ecosystem services to either the stewards or off-farm beneficiaries (Newcome et al. 2005). Further aims included: establishing initial contact with stewards of TRBs for future networking; identifying "hidden" TRBs that are not part of AES programmes; and determining whether TRB stewards differ from other farmers either in activities (hunting, fishing, on-farm entrepreneurism) or demographically (age, farm size).

In keeping with the conservation-relevance goal of the social-ecological inventory method, results of the postal questionnaire were examined in the context of integrated conservation management strategies (AM, ES, SES) and the current knowledge and institutional context in Finland.

The questionnaire is a part of COAST-MAN ecosystem assessment (SGA) in the western Gulf of Finland. COAST-MAN stands for Coastal Management and is a UNEP-endorsed Millennium Ecosystem Assessment Follow-up Programme Sub-Global Assessment (SGA).

\section{Materials \& Methods}

Field research for this study was carried out in Raasepori Municipality, located on the Baltic Sea coast in SW Finland (Fig 1). The total area of Raasepori is $2354 \mathrm{~km}^{2}$, of which $1215 \mathrm{~km}^{2}$ is land (Raasepori Municipality 2010). The total population is 29,000 persons (Ekenäs Stad et al. 2006). Previous inventories estimate there are approximately 330 ha of managed TRBs (primarily seashore meadows and grazed forests/woodland meadows) in Raasepori (Pykälä \& Bonn 2000). The area contains a high proportion of all managed TRBs in Uusimaa Province (Pykälä \& Bonn 2000; Ekenäs Stad et al. 2006). 
This study was conducted using a mixed methods strategy (Denscombe 2010). It was based on an original postal questionnaire (Annex I), literature and agricultural statistics. Agricultural statistics for Raasepori Municipality were provided by the Finnish Agency for Rural Affairs (MAVI) and the Finnish Food Safety Authority (EVIRA) (Table 1) and were the most current available in 2009-2010. The sampling frame for the postal questionnaires was all farms registered with MAVI in Raasepori Municipality $(n=326)$. Postal questionnaires were sent in May 2010 to the representative of each farm registered with MAVI.

\begin{tabular}{|l|}
\hline Auxiliary Variables \\
Farmer age \\
Farm production type \\
Farm size (ha) \\
Farm animals \\
AES types (2005-2009) \\
\hline
\end{tabular}

Tab 1. Auxiliary variables used in analysis. Information on farms in Raasepori was provided primarily by Finland's Bureau for Rural Affairs (MAVI), with some supplementary information from The Foods Safety Authority (EVIRA).

Questionnaire packets included a cover letter and self-addressed prepaid envelope for returning the completed questionnaire. The bilingual quality of the region was taken into account in the research. Questionnaires and accompanying information were sent in Swedish or Finnish, depending upon mother tongue of the recipient (as determined by recipients' names). In cases where the first language of the recipient was ambiguous, all information was sent in both languages. No deadline for return of the survey was given, but nearly all returned questionnaires were received within 5 weeks of being posted to recipients. Serial numbers were assigned to each questionnaire recipient to ensure confidentiality and promote candid responses. Thus, respondents remained anonymous during processing of the questionnaires and analysis of results, but can be traced for follow-up research.

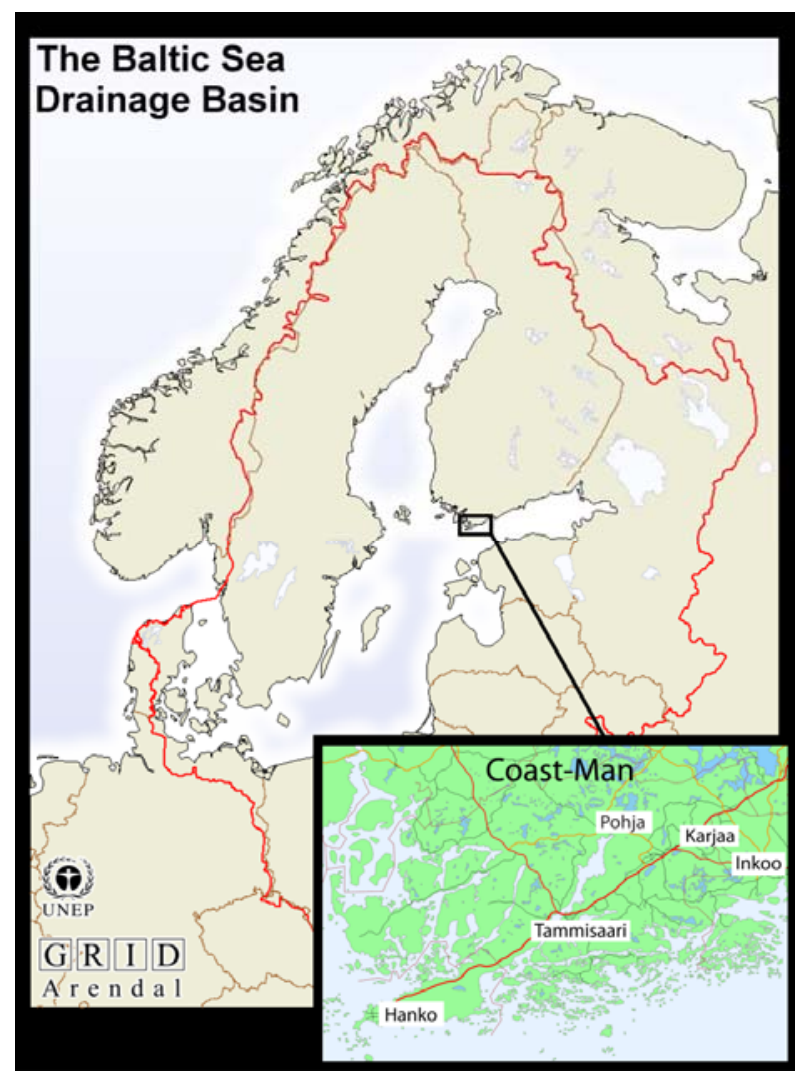

Fig 1. Baltic Sea Drainage Basin map (adapted from: Hugo Ahlenius \& UNEP/GRID-Arendal). The inset shows Raasepori Municipality, which includes Tammisaari, Pohja, Karjaa and Inkoo. Hanko Municipality is also part of the COAST-MAN Sub-global assessment of which this study is a part but was not included in the study area because relatively little farming activity takes place there. 
The questionnaire was divided into two sections: Personal information and Information on TRBs (Table 2). The purpose of the personal information section was to collect variables that could be used to compare farms and their managers with TRBs to those without TRBs. We collected demographic information and asked respondents about specific activities on the farm. The activities included three categories: hunting, fishing, and economic activities that bring offfarm consumers to the farm. These variables were chosen to help us understand who TRB managers are and how they may differ from non-TRB farmers in typical nature-use activities and farm entrepreneurship. Hunting was used because it is a widely practiced activity in Finland, and the right of hunting an area rests with the landowner. According to the Finnish Hunting Association, there are approximately 300,000 people with hunting licenses in Finland. Hunting in Finland is a provisioning service for meat rather than trophy hunting. Landowners generally either consume the meat themselves or sell it. Anyone in Finland can hunt if they have a hunting license and permission of the landowner. Fishing activities were included because fishing is a traditional livelihood in the coastal region. Entrepreneurial activities were included to give an idea of the extent of farm tourism and direct sales and to explore whether there is a link between TRB management and business activities that bring the public to the farms. We hypothesised that TRB managers as a whole practice more diversified farming and are more likely to engage in innovative farm practices such as direct sales, mixed and organic farming and to be at least as active as non-TRB managers in traditional rural activities like hunting and fishing. Currently, the most up-to-date information on presence of TRBs is, arguably, MAVI statistics on AES for TRB conservation. AES statistics only tell us about TRBs that are in the system. We looked at age, farm size and presence of TRB to see what factors might affect participation in AES and whether the postal questionnaire was able to identify managers of "hidden" TRBs not part of AES.

\begin{tabular}{|c|c|c|c|}
\hline Section & Purpose & Variables used & $\begin{array}{l}\text { Number on } \\
\text { questionnaire }\end{array}$ \\
\hline \multirow[t]{9}{*}{ Personal } & Quality check & Serial number & 1 \\
\hline & & Identification verification & 2 \\
\hline & & Decision-maker status & 5 \\
\hline & & Ownership status & 6 \\
\hline & $\begin{array}{l}\text { Compare farms and their } \\
\text { stewards }\end{array}$ & Location & 3 \\
\hline & & Education & 4 \\
\hline & & $\begin{array}{l}\text { Presence of farm tourism, direct sales, } \\
\text { services }\end{array}$ & $7-9$ \\
\hline & & Hunting, fishing activities & $10-14$ \\
\hline & & Presence of managed or unmanaged & \\
\hline \multirow[t]{3}{*}{ TRBs } & Identify TRBs on farms & TRBs & $15-17$ \\
\hline & Identify TRB ecosystem services & Presence of non-agric. uses of TRBs & 18 \\
\hline & Identify off-farm use of TRB ES & Use of TRBs by off-farm people & 19 \\
\hline
\end{tabular}

Tab 2. The postal questionnaire was divided into two sections: personal and TRB.

In the second section, respondents were asked a series of questions about their TRBs. They were provided with a definition of TRBs to help them answer the questions (Annex I). Additionally, respondents were presented with two identical tables (Table 3 ) of short definitions of TRB types and asked in the first case to indicate whether or not they had managed TRBs of each type on their farms or under their management and, in the second case, whether or not they had remnants of these biotopes on their farms. 


\begin{tabular}{ll}
\hline Traditional rural biotope type & Definition \\
\hline Seashore meadow & meadows found along the seashore \\
Freshwater shore meadow & meadows found along lakes or rivers \\
Grazed forest & animals grazing in the forest \\
Open and wooded meadows & permanent pastures and meadows with trees \\
Heaths & very dry, open areas mostly dominated by heather \\
Other meadow types & Not included above
\end{tabular}

Tab 3. Types of TRBs on farms in Finland. Farmers were asked to identify which types of meadows they manage or have on their farms.

Results of the postal questionnaire were analysed using SYSTAT 12 (2007). Farm size (ha) and farm primary production type were used to test whether the returned postal questionnaires was representative of the farms in Raasepori Municipality. Primary production types were aggregated into 6 categories adapted from MAVI 2009 statistics. One value was missing from analysis of farm size because land area of farm was missing in the agricultural statistics. Two subsidy recipients could not be matched to farms in MAVI statistics, resulting in $n=328$ instead of the Raasepori farm population $n=326$. Where feasible (mainly in relation to AES), these two recipients were included in analyses. Age distribution was not applicable for four farms because the farms are owned by companies or similar structures.

Presence of on-farm alternative income generation (direct sales, farm tourism and farm services) was compared between those respondents that indicated they have managed TRBs and those who said they did not have managed TRBs in order to determine whether there were links between direct sales and services and presence of TRBs.

\section{Results}

\section{Raasepori farms}

The dominant primary production type for farms in Raasepori during 2009-2010 was outdoor crops, followed by cattle and dairy farming (Fig 2). The mean farm size, including all land-use types on the farm, was 48.3 ha $(\mathrm{N}=326, \pm$ std $=47.4)$. The mean average crop area for Raasepori farms was 45.2 ha, which is larger than the 36.7 ha of arable land on an average Finnish farm in 2010 (TIKE 2011). The average age of Raasepori farmers was, at 51.8 years old, the same as the average farmer age in Finland in 2010 (Tike 2011).

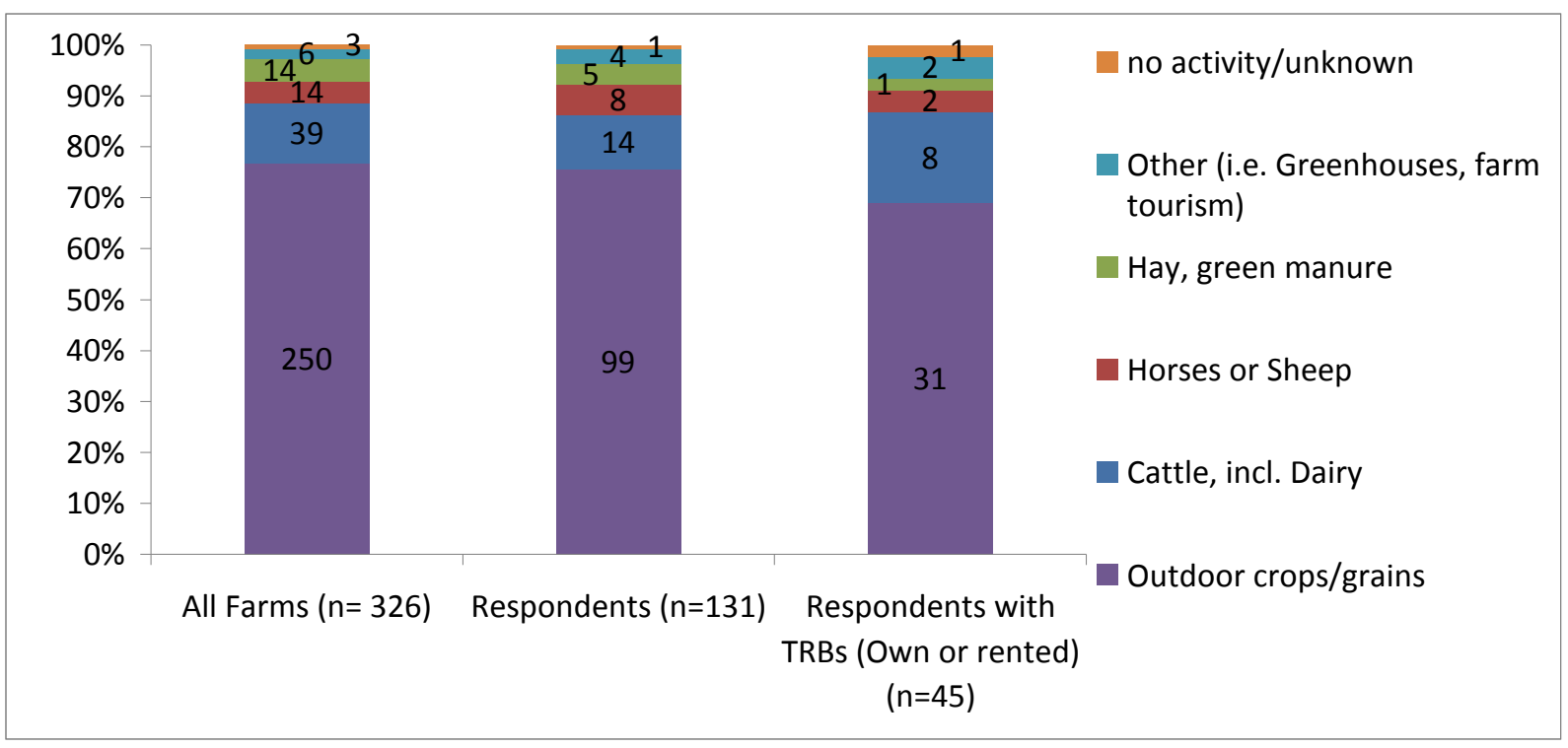

Fig 2. Number of farms in each primary production type (MAVI agricultural data 2009-2010) of all farms in Raasepori $(n=326)$, those that returned the postal questionnaire $(n=131)$ and those that said they have or rent managed TRBS $(n=45)$. 
In Raasepori Municipality, 62 people (representing 19\% of total MAVI-registered farms) received special agri-environmental subsidies during 2005-2009. 21 farmers in Raasepori received the TRB AES subsidy during 2005-2009.

\section{Postal questionnaire response}

The return rate for the postal questionnaire was $40.18 \%(131 / 326)$. Respondents and nonrespondents had the same farming type (production type; $x^{2}=4.885$, d.f. $=5.0, p=0.430$ ). Farm size was the same for respondents $(n=131$, mean $=54.2, \pm$ std $=54.7)$ and nonrespondents $(n=194$, mean $=44.27, \pm$ std $=41.4663)(2$ sample $t$-test: $t=1.860$, d.f. $=$ $323.000, p=0.064)$. There was no difference in age between respondents and nonrespondents.

\section{TRBs among respondents}

Of all AES recipients in Raasepori Municipality, 45\% (28/62) responded to the postal questionnaire (Table 4). $32 \%$ (42/131) of respondents said they have managed TRBs (Table 5). Farm size was not an indicator of presence or absence of TRBs on the farm (1-way ANOVA $F_{\text {d.f. }}$ $=0.931, P=0.397$ ). Most of the respondents receiving AES for landscape or biological diversity also had TRBs. Only two AES recipients who said they had TRBs did not receive either TRB or landscape/biological diversity AES.

$\begin{array}{lrrrr}\text { AES Subsidies } & \begin{array}{l}\text { Raasepori Farmers } \\ (n=328)\end{array} & \begin{array}{l}\text { Respondents } \\ (n=131)\end{array} & \begin{array}{l}\text { Have (or rent) } \\ \text { TRBs ( } n=45)\end{array} \\ \text { ALL AES } & 62 & 30 & 22 \\ \text { TRB } & 21 & 13 & 13 \\ \text { Landscape \& Biodiversity } & 22 & 17 & 16 \\ \text { Protected verges } & 14 & 4 & 3 \\ \text { Organic farming } & 21 & 11 & 8 \\ \text { Heritage breeds } & 5 & 3 & 2 \\ \text { Drainage pond } & 1 & 0 & 0 \\ \text { Manure management } & 2 & 0 & 0\end{array}$

Tab 4. Types of AES received during 2005-2009 by Raasepori farmers according to MAVI statistics. Two subsidy recipients could not be matched to farms in MAVI statistics, resulting in $n=328$.

\begin{tabular}{l|rrr}
\hline \multicolumn{1}{|c|}{$\begin{array}{c}\text { Presence of TRBs } \\
\text { TRBs }\end{array}$} & $\begin{array}{c}\text { Remnants } \\
\text { of TRBs }\end{array}$ & $\begin{array}{c}\text { Rent from } \\
\text { someone else }\end{array}$ \\
\hline Have & 42 & 17 & 11 \\
Don't have & 82 & 105 & 118 \\
Unsure & 6 & 7 & 0 \\
No answer & 1 & 2 & 2 \\
Total & 131 & 131 & 131
\end{tabular}

Tab 5. Postal questionnaire responses $(n=131)$ to questions about presence and management of TRBs (Annex 1: questions 15-17).

AES recipients were slightly younger than non-recipients $(t=-2.467$, d.f. $=90.237, p$-value $=$ 0.016 ) (Fig 3). Farm sizes of AES and non-AES recipients differed $(t=2.835$, d.f. $=62.388$, $p$ value $=0.006)$. The average farm size of AES recipients was 72 ha, while non-AES farmers' mean farm size was 43. ha (Fig 4). Difference remained when tested without the most extreme outlier (393 ha AES recipient) $(\mathrm{t}=3.046$, d.f. $=71.529$, $\mathrm{p}$-value $=0.003)$. 


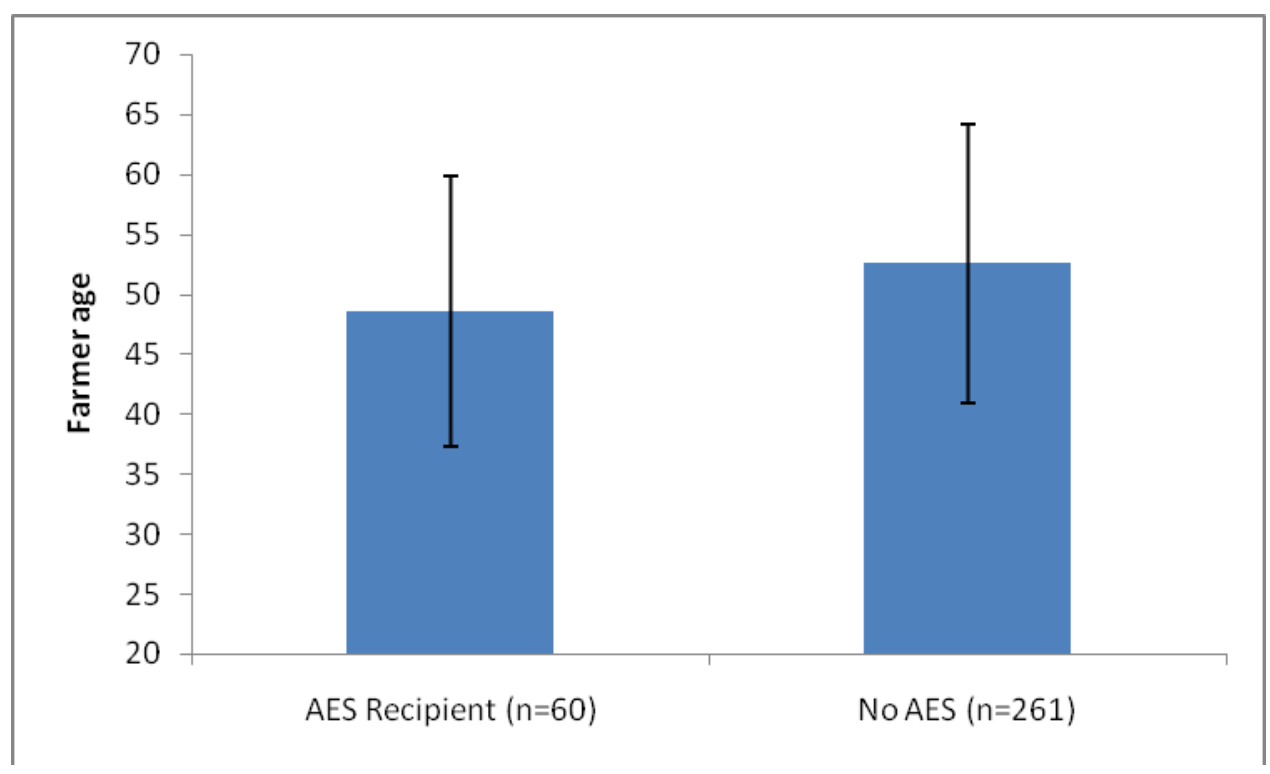

Fig 3. Age of AES recipients compared to non-recipients ( $N=321)$. Age is missing for farms not owned by individuals.

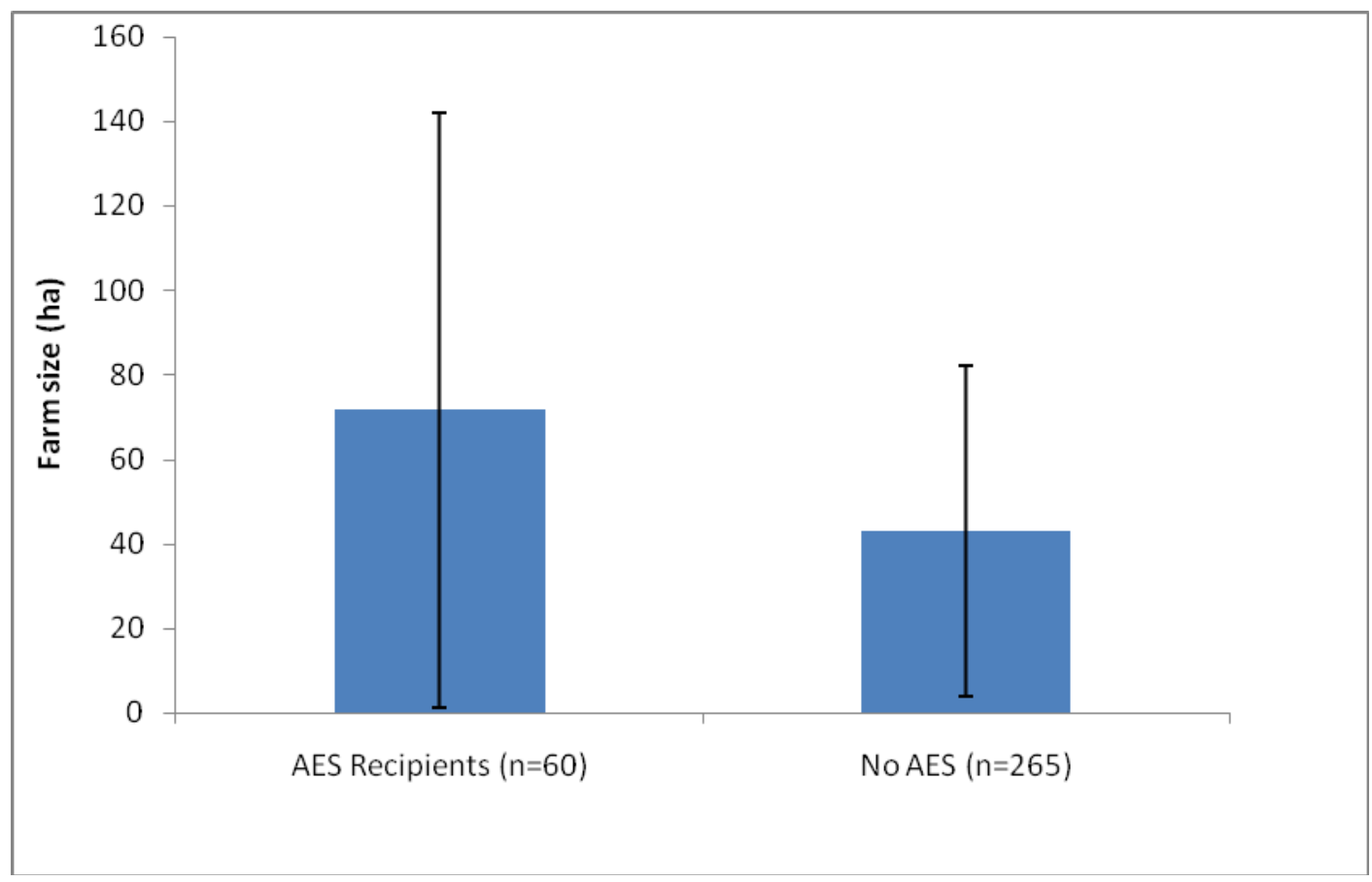

Fig 4. Farm size of AES recipients compared to non-recipients $(N=324)$. Farm size was unavailable for 1 farm.

\section{Farm tourism, direct sales and services}

$28 \%(36 / 131)$ of all respondents said they had economic activities that bring the public to the farm or result in farm name recognition through farm tourism, direct sales or services. Presence of activities differed between respondents with TRBs and those without TRBs $\left(x^{2}=\right.$ 9.900 , d.f. $=2.0, p=0.000$.). A total of $51 \%(23 / 45)$ of respondents with TRBs said their farm has direct sales, tourism or services. Only 14\% (11/79) of respondents without TRBs had these activities. 2/6 respondents unsure of whether or not they had TRBs have these activities on their farms. Non-response to this question was $5 \%$.

\section{Hunting and fishing}

$85 \%(112 / 131)$ of respondents said that some type of hunting takes place on their farms (Fig 5). There was no difference in response between those with TRBs and those without $\left(x^{2}=2.957\right.$, d.f. $=2.0, p=0.228)$. $35 \%(46 / 131)$ of respondents said they practice some type of fishing. None of the respondents engaged in commercial fishing for more than $20 \%$ of their income, but 
three respondents (all with TRBs) said they engaged in income-generating fishing for less than $20 \%$ of their income. Hobby fishing was more popular. Half $(24 / 45)$ of farmers with managed TRBs and $27 \%(21 / 79)$ of respondents without TRBs indicated that they fish recreationally.

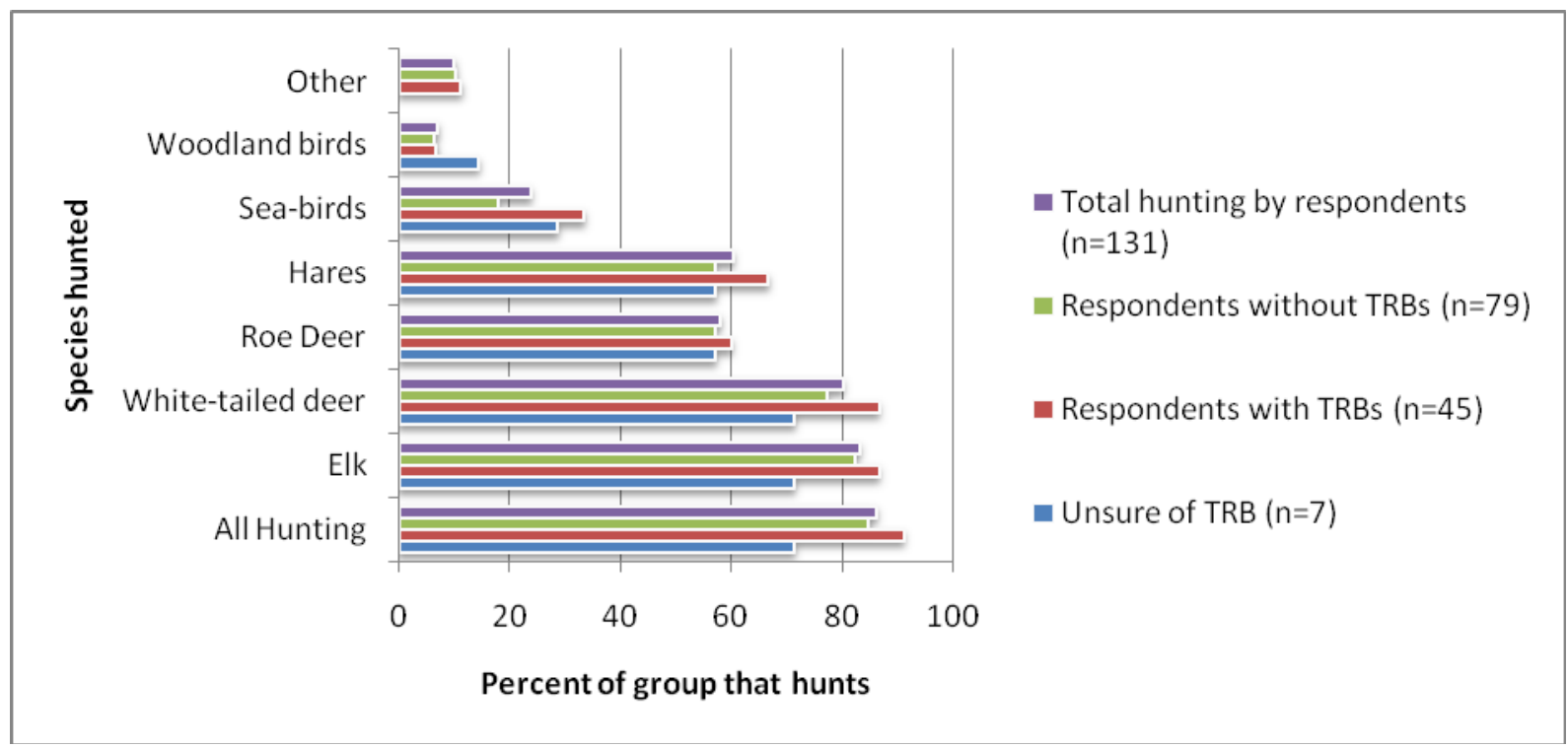

Fig 5. Percentage of farmers that hunt, by species. Hunting is widely practiced on both farms with and without TRBs. The most commonly hunted species, elk and whitetailed deer, require membership to a hunting organisation. Typically, lands are pooled together to create a contiguous area to meet the hunting regulations for these species (area must be over 1000 ha).

\section{Non-agricultural ecosystem services}

One-third of respondents said that their TRBs are used for non-agricultural activities, including but not limited to hunting, berry/mushroom collecting and bird watching (Table 6). 13\% (6/45) of respondents either failed to answer this question or answered "don't know".. $27 \%$ of respondents said that people from off-farm use their TRBs for non-agricultural activities. Nonresponse/don't know was $9 \%$ (4/45) for this question.

\begin{tabular}{|c|c|c|}
\hline $\begin{array}{l}\text { Presence of } \\
\text { activities and of } \\
\text { off-farm users }\end{array}$ & $\begin{array}{l}\text { Non-ag } \\
\text { activities }\end{array}$ & $\begin{array}{l}\text { Off-farm } \\
\text { users }\end{array}$ \\
\hline Yes & 15 & 12 \\
\hline No & 24 & 29 \\
\hline Don't know & 2 & 1 \\
\hline Non-response & 4 & 3 \\
\hline Total & 45 & 45 \\
\hline
\end{tabular}

Tab 6. Non-agricultural ecosystem services and off farm users.

\section{Discussion}

\section{Response bias}

The two main challenges of postal questionnaire-based research are obtaining sufficient responses and representativeness of responses. By some measures, a $40 \%$ response rate for a postal questionnaire is considered low (Bryman 2008). This study was initiated as a census of all farms in Raasepori, so results are $40 \%$ the total population (as opposed to a sample of the population) and provide sufficient starting point to explore who manages TRBs and whether TRBs provide ecosystem services or benefits beyond the primary agriculture services and conservation repository for which they are normally recognized. Results, however, should be considered in the context of over-representation of some groups, particularly AES recipients. 
A disproportionately high percentage of AES recipients answered the postal questionnaire compared to the general farm population for Raasepori. There is a risk of over-representing AES recipients compared to non-recipients. For example, respondents may be more active in agri-environmental protection or more knowledgeable about subsidy structures than the general farming populace. Responses to address possible AES bias for a more detailed study could be either to weight responses to account for non-response or to try to increase response rate through follow-up. Follow-up could, for example, include a second mailing as suggested by Bryman (2008) to non-respondents reiterating the goals of the questionnaire and reminding them to fill in the questionnaire.

\section{Non response and uncertainty to questions}

Recipients of the questionnaire were provided with a definition of TRBs for clarity and to reduce self-interpretations of the term, but it was expected that professional farmers and farm owners would be familiar with TRBs already. Uncertainty and non-response to questions about TRBs indicated that this was not universally true. Eight respondents gave conflicting answers by marking that they did not have or rent TRBs but then marked at least one TRB type that they manage or is managed on their farm. Additionally, six respondents were unsure whether they had TRBs. Further, type of TRBs on farms or under management could not be analysed because of the high level of non-response $(69.08 \%)$ to these questions. Response fatigue may be one factor explaining this selective non-response, as TRB type was the final section of the questionnaire. Alternatively, some respondents may have marked only the TRB types they have and failed to confirm with a "no" the TRB types they did not manage. If this is the case, then non-response for TRB type resulted from error in questionnaire design.

It is unclear why respondents were confused about whether they had TRBs, even when definitions were provided. Familiarity or with AES may affect knowledge regarding conservation sites like TRBs. None of the six farmers who were uncertain about whether they have TRBs are in the AES programme, while only two of the eight respondents who gave conflicting answers about presence of TRBs receive AES.

Another possible explanation for uncertainty or confusion is that respondents were unclear whether they should include conservation sites other than TRBs or if they should include TRBs that are not managed according to AES rules. Non-TRB sites could include rocky areas in fields, set asides, or permanent pastures, which are eligible for AES (Table 4) but are not TRBs. TRBs not managed according to AES regulations could include those that are fenced together with permanent pastures or hay fields or TRBs where animals receive supplementary fodder. Lack of extension services combined with the often bureaucratic language of AES and other EU programmes that associate TRBs with a set of regulations rather than as an agricultural landscape or land-use type may confuse farmers about what constitutes a TRB.

\section{Identifying "hidden" TRBs}

The postal questionnaire identified stewards of TRBs who do not belong to AES for TRBs. Follow-up is needed to verify whether these recipients do, indeed, have managed TRBs, but the postal questionnaire gives us a starting point. One factor affecting participation in AES was size of the farm under management, with larger farms more likely to belong to AES than smaller farms. One explanation for this is that small-holders may be less likely to participate in AES because of the burden of the application process. Applications (and associated paperwork) and inspections for AES are the same, regardless of farm size or money dispensed. Participation by small-holders is desirable for conservation, since multiple studies support the notion that practices adopted by small-holders generally favour biodiversity compared to practices of larger farms (Marini et al. 2011).

\section{TRB managers and rural livelihoods}

Similar to the rest of the population, TRB owners and managers range from small-holders to large landowners and, according to questionnaire responses, most have hunting on their farms. Game animals hunted in particular are hares, white tailed deer, roe deer and moose, all of 
which use elements of the agricultural landscape at least seasonally. In some activities, TRB managers were more highly represented. They were somewhat more active in fishing, and were the only farmers that fished commercially (although only $<20 \%$ of their income). The questionnaire also established that both TRB stewards and off-farm people benefit from non-agricultural ecosystem services provided by TRBs. Follow-up research is needed in order to identify and determine the extent and value of these ecosystem services to farmers and communities.

TRB managers were more active in on-farm entrepreneurial activity (sale of farm goods and services) than respondents without TRBs. TRB managers also participated more in AES than other respondents. This supports our hypothesis that TRB owners are more diversified and likely to engage in innovative farm practices than their counterparts without managed TRBs.

It is also possible that there is a link between TRBs and these activities. Since $1 / 3$ of all farms with TRBs also had direct sales or services, TRBs may be coupled to meat production through direct sales to customers or through farm tourism. The TRB link to direct sales was stronger than that of organic farming. Only 4/30 respondents with direct sales and services received AES for organic farming (indicator of organic farming methods), but all four of these respondents said they have managed TRBs.

The example of the relationship between TRB management and on-farm entrepreneurship illustrates the types of links that can help describe who the stewards are as a group. Learning more about the stewards can be used toimprove policy. Currently, the AES system is "risk based" which, should reduce inspection burdens when everything is in order. In practice, it doesn't work this way because the system considers TRBs as well as all kinds of other special environmental measures to be risk (Åberg, 2011). So, if farmers receive AES for multiple activities, they are likely to be flagged for inspection more frequently. Simply identifying that AES farmers with TRBs differ from the main farm population in areas such alternative farm income-generation activities could be used to improve the AES inspections system by making a more accurate profile of AES recipients. This, in turn, could redirect inspection and extension services to where they are needed and reduce the inspection burden on farmers.

Although agricultural production is the primary direct use ecosystem service provided by TRBs, responses indicate that other products and benefits are derived from TRBs and that off-farm people also utilise TRBs for some of these purposes. Non-agricultural ecosystem services may be virtually invisible in planning, since agricultural use, biodiversity conservation and, perhaps to a lesser extent landscape, are the primary targets of TRB policy. This underscores the importance of understanding, even quantifying, the real value of these landscapes, including their ecosystem services. Accurate decision-making requires an understanding of what bundles (Raudsepp-Hearne et al. 2010) of ecosystem services are supported by TRBs and who benefits from them. Without knowing the value and use of these ecosystem services, it is impossible to accurately make decisions on trade-offs between different management, land use and policy options.

\section{TRB conservation and management strategies}

Pullin et al. (2009) point out that European conservation efforts focus on semi-natural habitats in cultural landscapes because of a lack of natural and pristine areas and the swift changes that semi-natural habitats have undergone. Decline of traditional farming, especially in marginal and semi-natural agricultural landscapes is largely irreversible due to larger social transformation, although AES can help support these landscapes (Marini et al. 2011). AES, Natura 2000, and other conservation programmes are indicators that HNV and associated conservation values are already embedded in strategy for traditional rural biotope management at the policy level.

A relatively large portion of Finland's utilised agricultural area is covered by AES (EEA 2004). In Raasepori, approximately $19 \%$ of farmers participate in AES. In Finland, AES is characterized by a strong top-down approach to management regulation (Siebert et al. 2006). In the case of TRBs, the current management approach fails to ensure the continued management of these endangered landscapes and their associated biodiversity (Salminen et al. 2000). AES is arguably the primary and most promising conservation mechanism for TRBs at the national and 
European levels. AES will be overhauled in the upcoming 2013 Common Agricultural Policy (CAP) reform. The CAP reform offers an opportunity to improve AES. The Finnish forestry authority Metsähallitus, for example, has created an expert panel to review AES and make suggestions for the 2013 CAP reform (Metsähallitus 2011). We have compiled our own suggestions based on our postal questionnaire and literature regarding the state of TRBs in Finland.

\section{Develop integrated evidence-based policy}

Evidence-based policy should make use of conservation policy tools such as AM and ecosystem services. Further, it should be constructed with an understanding of the socialecological drivers of the system, as these directly effect management decisions on the ground. AM should include the three key stakeholder groups: farmers, conservation researchers and policy makers.

Although TRBs are part of the historical rural landscape, management policy and practice needs to be pulled into the $21^{\text {st }}$ century, particularly if AES for TRBs is to attract more participants. This means that policy goals must be well articulated, and policy must be relevant and practical for farmers. Regulations for AES-based TRB management should be stringent enough to fulfil conservation goals without unduly burdening farmers with bureaucracy or requirements irrelevant to long-term conservation goals. Conservation researchers should establish indicators for monitoring TRBs and be at the forefront of establishing conservation goals and priorities.

Policy is more likely to be adopted if it considers the motivations, drivers, and trade-off decisions that influence management decisions. The role of TRBs in the social-ecological system needs to be better understood and TRB stewards acknowledged for providing society with ecosystem services that reach beyond their own farms. For example, the value of cultural ecosystem services of TRBs to tourism and marketing of regional food and culture should be explored. The value of supporting and regulating ecosystem services to agriculture and waterways should also be included in the value of TRBs to farms and society. Wet grasslands, for example, provide important supporting and regulating services, including flood alleviation, groundwater recharge, water filtration and water quality improvement (Benstead et al. 1999). Seashore-, riparian-, and other seasonally flooded low-lying wet grasslands throughout the Nordic countries and the Baltic region are also important bird habitats. In Raasepori Municipality, the most important wet grasslands in terms of abundance and agricultural activities are the seashore meadows. Grazing of seashore meadows creates a suite of ecosystem services, including suppression of common reed (Phragmites australis), fodder production and an aesthetically desirable open landscape. Understanding of these bundles and complimentary effects of management is important to making trade-off decisions in policy and management and raising the profile of these sites.

\section{Strengthen the knowledge base}

Effective TRB conservation is hindered by lack of indicators, data and monitoring of TRBs. The most effective management practices for conservation of TRBs may differ from historical management. Certainly management priorities for many TRBs have shifted over the years from production-based ecosystem services (fodder) to cultural and conservation-based values. Unfortunately, conservation management decisions tend to be based more on anecdotal evidence or historical management than the consequences of current practice (Pullin \& Knight 2003; Sutherland et al. 2004).Currently, we lack data the to say what the best management techniques are for the suite of management goals associated with TRBs (species conservation, ecosystem services, agricultural production). A recent assessment of Finland's HNV) farmlands noted that Finland has neither data nor possibility to monitor changes in the quality of the HNVareas, including that of TRBs (Heliolä et al. 2009). Similarly, the expert group on TRBs in Finland noted a large gap in knowledge on the current status and ecosystem function of TRBs and recommended more research into these areas (Raunio et al. 2008). The knowledge gaps hindering development of TRB conservation in Finland can be summarized as: 
- $\quad$ Lack of information of value of TRBs in providing ecosystem services;

- $\quad$ Lack of knowledge on extent and quality of TRBs in terms of habitat and biodiversity;

- Institutional lag in incorporating farmer \& landowner experiences and requirements into policy and regulation.

\section{Develop mechanisms for soliciting and responding to feedback from farmers}

Flexibility in programmes is key to benefiting from farmer experience and farmer-generated knowledge. The knowledge gaps above indicate a strong need for research development in multiple areas of TRB conservation and management, but they also show that an AM approach that includes farmer feedback and participation is needed both to address the problem of institutional lag, but also to gather knowledge and data for assessing the condition of TRBs and the ecosystem services they provide. One of the areas in which farmer input is invaluable is in identifying practical problems in implementing management regulations. Further, farmers may have ideas about improving management that could be tried out or researched. Feedback and suggestions can help guide research and refine policy.

\section{Strengthen extension services}

Focus should shift from an inspection to extension-based approach. The level of participation in AES and entrepreneurial activities evinced by TRB owners and managers in this study suggest that planners and extension agents could find stakeholders willing to participate as active stakeholders in AM. TRB owners have also participated in the past in TRB conservation programmes in Raasepori initiated by the municipality (Ekenäs Stad 2008). An AM-inspired extension and inspection service could improve innovation by providing an opportunity for farmers to discuss management with officials and even try out new management techniques on a test basis. Such collaborations could result in farmer-generated knowledge that has legitimacy in both the research and farming communities.

\section{Conclusion}

This research succeeded in identifying TRBs and their stakeholders in Raasepori municipality and indicates that TRBs may well provide a multitude of ecosystem services and benefits outside of agricultural production and biodiversity conservation. Participation by $40 \%$ of the farms in Raasepori in this study indicated that farmers in this region are not averse to participating in research directly relevant to agriculture and farm management. This finding is encouraging because the strategies outlined for improving TRB policy and management are highly dependent on stakeholder cooperation.

This study was first step in a social-ecological inventory (Schultz et al. 2007) of TRBs in SW coastal Finland. The postal questionnaire was invaluable in identifying TRB stewards, providing information regarding TRB use, and establishing contact for further research. Based on results of the questionnaire and literature of the state of affairs in regard to TRB conservation in Finland, we are able to make practical suggestions for improvement of AES, the most valuable conservation mechanism for TRBs in Finland and in much of Europe.

Multiple knowledge gaps have been identified through this research. Some of these gaps will be addressed through the on-going social-ecological inventory of TRBs in SW coastal Finland. Indepth interviews with questions directed in part by the results of the postal questionnaire have been developed for farmers with TRBs. Through interviews with farmers, we aim to identify management activities undertaken, management motivations (and challenges), and ecosystem services targeted in management in TRBs. Additionally, we plan to interview agriculture and environmental officials responsible for TRB policy to establish the goals of TRB policy and how policy is being directed to address challenges in TRB conservation. 


\section{Acknowledgements}

Special thanks to all of the farmers and farm owners who participated in the postal questionnaire. Several colleagues from Aronia R\&D assisted with this research. Nora Wilmi translated the postal questionnaires from English to Swedish and Finnish. Mari Pihlajaniemi and Anu Vehmaa contributed to the Finnish language translations. Anu Vehmaa and Eliecer Diaz assisted with statistical analysis. Jon Brommer commented on drafts of the manuscript.

This research is a part of COAST-MAN ecosystem assessment, Finland's first UNEP-endorsed sub-global ecosystem assessment under the Millennium Ecosystem Assessment Follow-up Programme.

Funding for this project was provided by Aronia Research and Development, Finnish Academy, Svenska Kulturfonden, and Oskar Öflund Foundation.

References

[1] Åberg, J. September 2011. Personal communication. MTK Central Union of Agricultural Producers and Forest Owners (MTK).

[2] Ahlenius, H. (2001). UNEP/GRID-Arendal, Baltic Sea drainage basin, UNEP/GRIDArendal Maps and Graphics Library, http://maps.grida.no/go/graphic/baltic_sea_drainage_basin (Accessed 29 March 2011).

[3] Allen, C., Fontaine, J., Pope, K. \& Garmestani, A. (2011). Adaptive management for a turbulent future. Journal of Environmental Management 92(5), 1339-1345. Doi: 10.1016/j.jenvman.2010.11.019

[4] Andersen, E., Baldock, D., Bennett, H., Beaufoy, G., Bignal, E., Brouwer, F., Elbersen, B., Eiden, G., Godeschalk, F., Jones, G., McCracken, D., Nieuwenhuizen, W., van Eupen, M., Hennekens, S., \& Zervas, G. (2003). Developing a High Nature Value Farming Area Indicator._Internal Report for the European Environment Agency. IEEP, 2007. http://www.eea.europa.eu/data-and-maps/indicators/agriculture-area-under-managementpractices/developing-a-high-nature-value (accessed 19/3/2011)

[5] Beaufoy, G. \& Cooper, T. (2009). Guidance Document: the Application of the High Nature Value Indicator 2007-2013. European Communities

http://ec.europa.eu/agriculture/rurdev/eval/hnv/guidance_en.pd.f. (accessed 30/1/2011)

[6] Benstead, P.J., Jose, P.V., Joyce, C.B., Wade, P.M. \& (1999). European Wet Grassland: Guidelines for Management and Restoration. RSPB, Sandy.

[7] Berkes, F., Colding, J. \& Folk, C. (2008). Navigating Social-Ecological Systems: Building Resilience for Complexity and Change. Cambridge University Press.

[8] Bryman, A. (2008). Social Research Methods: $3^{\text {rd }}$ edition. Oxford University Press.

[9] Denscombe, M. (2007). The Good Research Guide: For Small-Scale Social Research Projects, $3^{\text {rd }}$ edition. Mcgraw Hill Open University Press.

[10] EEA (2004). High Nature Value Farmland: Characteristics, Trends and Policy Challenges. EEA Report 1/2004 Luxembourg: Office for Official Publications of the European Communities. http://www.eea.europa.eu/publications/report_2004_1 (accessed 30/1/2011)

[11] EEA (2010). 10 Messages for 2010: Cultural Landscapes and Biodiversity Heritage. European Environment Agency, Denmark. Doi: 10.2800/5664 http://www.eea.europa.eu/publications/10-messages-for-2010-2013 (accessed 30/1/2011)

[12] Ekenäs Stad (Tammisaari/Ekenäs Municipality, now Raasepori Municipality), 2006. Skärlandet Landskapsvårdsomrade: Skötsel- och Användningsplan/Skärlandet MaisemaAlue: Hoito- ja Käyttösuunnitelma (Skärlandet Landscape Conservation Area: Management and Use plan). (In Swedish and Finnish, summary in English). 
[13] Gregory, R., Ohlson, D. \& Arvai, J. (2006). Deconstructing adaptive management: criteria for applications to environmental management. Ecological Applications 16, 2411-2425. Doi: 10.1890/1051-0761(2006)016[2411:DAMCFA]2.0.CO;2

[14] Haines-Young, R. \& Potschin, M. (2010). Chapter 6: The links between biodiversity, ecosystem services and human well-being. In Raffaelli, D.G. and C.L.J. Frid (Eds.), Ecosystem Ecology: A Synthesis (pp. 110-139). Cambridge: Cambridge University Press.

[15] Heliölä J., Lehtomäki, J., Kuussaari, M., Tiainen, J., Piha, M., Lehtonen, H., Miettinen, A. \& Koikkalainen, K., 2009. Luonnoltaan Arvokkaat Maatalousalueet Suomessa- Määrittely, Seuranta ja Hoidon Taloudelliset Edellytykset. MMM 1/2009. Vammalan Kirjapaino Oy. http://www.mmm.fi/attachments/mmm/julkaisut/julkaisusarja/2009/5HZiK6X4l/MMMjulkaisu 2009_1.pd.f. (accessed 30/1/2011)

[16] Kröger, L. (2005), Development of the Finnish agri-environmental policy as a learning process. European Environment 15, 13-26. Doi: 10.1002/eet.370

[17] Marini, L., Klimek, S. \& Battisti, A. (2011). Mitigating the impacts of the decline of traditional farming on mountain landscapes and biodiversity: a case study in the European Alps. Environmental Science \& Policy 14(3), 258-267. Doi: 10.1016/j.envsci.2010.12.003

[18] Metsähallitus (2011).

http://www.metsa.fi/sivustot/metsa/fi/Luonnonsuojelu/Yhteistyo/Tutkimusyhteistyo/Sivut/En nallistamisenjaluonnonhoidonasiantuntijayhteistyo.aspx (accessed 2/3/2011)

[19] Millennium Ecosystem Assessment (2003). Ecosystems and Human Wellbeing:

A Framework for Assessment._Washington D.C: Island Press,.

http://www.maweb.org/en/Framework.aspx (accessed 2/3/2011)

[20] Newcome, J., Provins, A., Johns, H., Ozdemiroglu, E. \& Ghazoul, J. (2005). Economic, Social and Ecological Value of Ecosystem Services: Literature Review. Final Report for Department for Environment, Food and Rural Affairs (DEFRA). London: Economics for Environment Consultancy (EFTEC).

[21] Pullin, A.S., \& Knight, T.M. (2003). Support for decision making in conservation practice: an evidence-based approach. Journal for Nature Conservation 11(2), 83-90. Doi: 1381/03/11/02-083

[22] Pullin, A.S., Báldi, A., Can, O.E., Dieterich, M., Kati, V., Livoreil, B., Lövei, G., Mihok, B., Nevin, O., Selva, N. \& Sousa-Pinto, I. (2009). Conservation focus on Europe: major conservation policy issues that need to be informed by conservation science. Conservation Biology 23(4), 818-824. DOI: 10.1111/j.1523-1739.2009.01283.x

[23] Pitkänen, M. \& Tiainen, J. (2001). Biodiversity of Agricultural Landscapes in Finland. Birdlife Finland Conservation Series no 3. Helsinki: Yliopistopaino.

[24] Pykälä, J. \& Bonn, T. (2000). Traditional Rural Biotopes in the Province of Uusimaa. Regional Environmental Publications 178. Finnish Environment Institute, Uusimaa Regional Environment Centre. Edita Ltd.

[25] Pykälä, J. (2000). Mitigating human effects on European biodiversity through traditional animal husbandry. Conservation Biology. 14(3), 705-712. Doi: 10.1046/j.15231739.2000.99119.x.

[26] Raunio, A., Schulman, A. \& Kontula, T. (Eds.), 2008. Assessment of Threatened Habitat Types in Finland-Parts 1 \& 2. The Finnish Environment 8/2008. Finnish Environment Institute. Vammala Kirjapaino OY, Vammala. English summary: http://www.ymparisto.fi/download.asp?contentid=86834\&lan=en.

[27] Raudsepp-Hearne, C., Peterson, G.D. \& Bennett, E.M. (2010). Ecosystem service bundles for analysing trade-offs in diverse landscapes. PNAS 107(11), 5242-5247. Doi: 10.1073/pnas.0907284107 
[28] Salminen, P. \& Kekäläinen, H. (Eds.), 2000. Perinnebiotooppien Hoito Suomessa. Perinnemaisemien Hoitotyöryhmän Mietintö. Finnish Environment Institute 443. Helsinki: Ympäristöministeriö.

[29] Schultz, L., Folke, C. \& Olsson, P. (2007). Enhancing ecosystem management through social-ecological inventories: lessons from Kristianstads Vattenrike, Sweden. Environmental Conservation 34(2), 140-152. DOI:10.1017/S0376892907003876.

[30] Siebert, R., Toogood, M. \& Knierim, A. (2006). Factors affecting European farmers' participation in biodiversity policies. Sociologia Ruralis, 46(4), 318-340. Doi: 10.1111/j.1467-9523.2006.00420.x

[31] Sutherland, W.J., Pullin, A.S., Dolman, P.M. \& Knight, T.M. (2004). The need for evidencebased conservation. Trends in Ecology and Evolution. 19(6), 305-308. Doi: 10.1016/j.tree.2004.03.018

[32] SYSTAT 12, 2007. Copyright (C) 2007 by SYSTAT Software, Inc. SYSTAT Software, Inc. Chicago, IL.

[33] Tike Information Centre of the Ministry of Agriculture and Forestry in Finland, 2011. Matilda Agricultural Statistics. http://www.maataloustilastot.fi/maatilojen-rakenne) (accessed 17/3/2011).

[34] Vainio, M., Kekäläinen, H., Alanen, A. \& Pykälä, J. (2001). Finnish Traditional Rural Biotopes: Final Report of the National Traditional Rural Biotope Project (Finnish only). Finnish Environment no. 527. Finnish Environment Institute. Vammalan Kirjapaino Oy, Vammala. http://www.ymparisto.fi/default. asp? contentid=49914\&lan=fi 


\section{Annex I: Postal Questionnaire for Farmers}

\section{Personal}

1. What is the number on the address sticker on the envelope?

2. Are you the person to whom the envelope is addressed?

$\square$ Yes

3. Where do you live? (check one)

$\square$ Skärlandet (Skåldö)

$\square$ Tammisaari

$\square$ Pohja
No,

Your name:

Date of birth:

Your gender:

4. Highest completed level of education (check one)

$\square$ Secondary school
$\square$ High School
$\square$ Trade School

5. Do you own or rent a farm(s)? $\square$ University: lower degree

$\square$ University: upper degree

$\square$ University: doctoral degree

Other:
Yes
$\square$ No
Don't know

6. Are you responsible (partly or wholly) for major land-use decisions on your farm (type and style of farming, types of crops and animals raised, land use, etc)?
$\square$ Yes
$\square$ No
Don't know

7. Does your farm have a bed \& breakfast, restaurant/café, summer cottages or other tourism accommodation or hospitality?
$\square$ Yes
$\square$ No
Don't know

8. Does your farm have a farm shop, self-picking or other direct sales to customers?
$\square$ Yes
$\square$ No
Don't know

9. Does your farm provide farm tours, riding stables, boating services or other recreation and tourism-related activities not mentioned above?
$\square$ Yes
No
Don't know

10. Are there hunting grounds on your farm?

$\square$ Yes $\quad \square$ No $\square$ Don't know
If yes, what species are hunted?
$\square$ Moose
$\square$ Deer
$\square$ Hares

11. Do you hunt or belong to a hunting association?
$\square$ Yes
$\square$ No
Other

12. Do you receive at least $20 \%$ of income from fishing, or if retired, received income prior to retirement?
$\square$ Yes
$\square$ No
Other 
13. Do you receive some income, but less than $20 \%$, from selling fish or seafood?

$\square$ Yes $\quad \square$ No $\quad \square$ Other

14. Do you fish for recreation or for your own use?

$\square$ Yes $\quad \square$ No $\square$ Other

\section{Management of Traditional Rural Biotopes}

In Finland, grazed meadows, forests and woodlands were traditionally an important part of agricultural production. Collectively, these are known as traditional rural biotopes. Traditional management of these sites included, for example, animal grazing and haying. As agriculture has changed, many traditional rural biotopes have been converted into fields or forests. Some farms still manage traditional rural biotopes, while other farms have remnants of old traditional rural biotopes. Remnants are often abandoned meadows or woodlands that still show the effects of past grazing or other management through, for example, plant species often found in traditional rural biotopes.

15. Are there managed traditional rural biotopes on your farm?
$\square$ Yes
$\square$ No
Don't know

16. Are there old meadows or remnants of other traditional rural biotopes that are no longer managed on your farm?
$\square$ Yes
$\square$ No
Don't know

17. Some farmers rent or have agreements with landowners to maintain their meadows or other traditional rural biotopes. Do you rent traditional rural biotopes from anyone else or manage someone else's traditional rural biotopes?
$\square$ Yes
$\square$ No
Don't know

If you answered Yes to one or more of questions 15-17, please continue the questionnaire. If you answered No or Don't know to all of questions 15-17, please stop here and return your survey in the envelope provided. Feel free to leave any comments you may have regarding the survey or your answers.

Thank you for your participation!

Comments 
18. In addition to your agricultural activities, are your traditional rural biotopes used for other activities including (but not limited to) hunting, berry/mushroom collection, birdwatching, fishing or boating?

$\square$ Yes $\quad \square$ No $\square$ Don't know

19. Do other people besides yourself (neighbours, associations, summer residents, etc) use your meadows for any activities (such as those listed above)?
$\square$ Yes
No
Don't know

Please mark which types of traditional rural biotopes are MANAGED on your farm or lands you rent (Check all that apply)

Seashore meadows(meadows found along the seashore)

Riparian meadows (meadows found along lakes or rivers)

Grazed forests (animals grazing in the forest)

Wooded meadows (permanent pastures and meadows with trees)

Heaths (very dry, open areas mostly dominated by heather)

Other meadow types of semi-natural meadows

Please mark which types ABANDONED or UNMANAGED meadows and grazed forests are found on your farm (Check all that apply)

\begin{tabular}{|l|l|l|l|}
\hline Seashore meadows(meadows found along the seashore) & Yes & Non't know \\
\hline Riparian meadows (meadows found along lakes or rivers) & & \\
\hline Grazed forests (animals grazing in the forest) & \\
\hline Wooded meadows (permanent pastures and meadows with trees) & \\
\hline Heaths (very dry, open areas mostly dominated by heather) & \\
\hline Other meadow types of semi-natural meadows & & \\
\hline
\end{tabular}

Thank you for your participation in this survey. All answers will be handled in strictest confidentiality and for research purposes only.

Comments 